OPEN ACCESS

Edited by:

Olivier Cuvillier

Centre National de la Recherche

Scientifique, France

Reviewed by:

Hany A. Omar,

University of Shariah, United Arab

Emirates

Paul William Sylvester,

University of Louisiana at Monroe,

USA

${ }^{*}$ Correspondence:

Marc Poirot

marc.poirot@inserm.fr

${ }^{+}$Joint first authors.

‡Present address:

Farid Khallouki,

Natural Substances Biochemistry

Laboratory, LBSN, FSTE,

Errachidia, Morocco,

Philippe de Medina,

Affichem S.A., Toulouse, France

Specialty section:

This article was submitted to Pharmacology of Anti-Cancer Drugs,

a section of the journal

Frontiers in Oncology

Received: 12 October 2015

Accepted: 06 December 2015

Published: 05 January 2016

Citation:

Khallouki F, de Medina P,

Caze-Subra S, Bystricky K,

Balaguer $P$, Poirot $M$ and

Silvente-Poirot S (2016) Molecular

and Biochemical Analysis of the

Estrogenic and Proliferative

Properties of Vitamin E Compounds.

Front. Oncol. 5:287.

doi: 10.3389/fonc.2015.00287

\section{Molecular and Biochemical Analysis of the Estrogenic and Proliferative Properties of Vitamin E Compounds}

\author{
Farid Khallouki ${ }^{1,2,3 \dagger \neq}$, Philippe de Medina ${ }^{1+\neq}$, Stéphanie Caze-Subra ${ }^{4}$, Kerstin Bystricky $^{4}$, \\ Patrick Balaguer ${ }^{5,6}$, Marc Poirot ${ }^{1,2,3 *}$ and Sandrine Silvente-Poirot ${ }^{1,2,3}$ \\ ${ }^{1}$ INSERM UMR 1037, Cancer Research Center of Toulouse, University of Toulouse III, Toulouse, France, ${ }^{2}$ Université Paul \\ Sabatier, Toulouse, France, ${ }^{3}$ Institut Claudius Regaud, Toulouse, France, ${ }^{4}$ Laboratoire de Biologie Moléculaire Eucaryote, \\ CNRS, Toulouse, France, ${ }^{5}$ Université de Montpellier, Montpellier, France, ${ }^{6}$ INSERM U1194, Institut de Recherche en \\ Cancérologie de Montpellier, Montpellier, France
}

Tocols are vitamin E compounds that include tocopherols (TPS) and tocotrienols (TTs). These lipophilic compounds are phenolic antioxidants and are reportedly able to modulate estrogen receptor $\beta$ (ER $\beta$ ). We investigated the molecular determinants that control their estrogenicity and effects on the proliferation of breast cancer cells. Docking experiments highlighted the importance of the tocol phenolic groups for their interaction with the ERs. Binding experiments confirmed that they directly interact with both ER $\alpha$ and ER $\beta$ with their isoforms showing potencies in the following order: $\delta$-tocols $>\gamma$-tocols $>\alpha$-tocols. We also found that tocols activated the transcription of an estrogen-responsive reporter gene that had been stably transfected into cells expressing either ER $\alpha$ or ER $\beta$. The role of the phenolic group in tocol-ER interaction was further established using $\delta$-tocopherylquinone, the oxidized form of $\delta$-TP, which had no ER affinity and did not induce ER-dependent transcriptional modulation. Tocol activity also required the AF1 transactivation domain of ER. We found that both $\delta$-TP and $\delta$-TT stimulated the expression of endogenous ER-dependent genes. However, whereas $\delta$-TP induced the proliferation of ER-positive breast cancer cells but not ER-negative breast cancer cells, $\delta$ - $T$ inhibited the proliferation of both ER-positive and ER-negative breast cancer cells. These effects of $\delta$ - $T$ were found to act through the down regulation of HMG-CoA reductase (HMGR) activity, establishing that ERs are not involved in this effect. Altogether, these data show that the reduced form of $\delta$-TP has estrogenic properties which are lost when it is oxidized, highlighting the importance of the redox status in its estrogenicity. Moreover, we have shown that $\delta$-TT has antiproliferative effects on breast cancer cells independently of their ER status through the inhibition of HMGR. These data clearly show that TPs can be discriminated from $T$ Ts according to their structure.

Keywords: estrogen receptor alpha, estrogen receptor beta, vitamin E, molecular modeling, gene transcription, HMG-CoA reductase, breast cancer, proliferation 


\section{INTRODUCTION}

Vitamin E was first characterized in wheat germ oil and lettuce in 1922 (1). Vitamin E compounds are also known as tocols and include eight structurally related forms separated into two groups: tocopherols (TPs), in which the isoprenoid side chain is saturated, and tocotrienols (TTs), in which the side chain is unsaturated. The $\alpha$-, $\beta$-, $\gamma$-, and $\delta$-TP and -TT isomers are named according to the number of methyl groups on the chromanol ring at the 3 , 5, and 7 positions (Figure 1). Vitamin E compounds have been extensively used in pharmacological studies due to their antioxidant properties; however, a major difference exists between TPs and TTs. TTs are potent down regulators of both HMG-CoA reductase (HMGR) and the isoprenoid-cholesterol biosynthesis pathway, and reduced cancer cell proliferation (2). In addition, TTs have been reported to induce cell cycle arrest and inhibit $\mathrm{NF \kappa B}$ pathways and angiogenesis (3-6). Compared to TTs, much more is known about the effects of TPs. $\alpha$-TP is quantitatively the major form of vitamin E found in humans and animals (7), whereas other TPs are present in various fat oils, such as palm oil (8) and argan oil (9). Many studies have focused their attention on vitamin E succinate (VES), a synthetic derivative of $\alpha$-TP in which the hydroxyl phenol is esterified through succinylation.
In contrast to $\alpha$-TP, VES displays antiproliferative properties through an as-yet undefined mechanism in vitro and in vivo (10) but does not have antioxidant properties due to the esterification of the phenolic group. Vitamin E are fat-soluble antioxidants, and numerous studies have proposed that they can help in preventing or modulating diseases associated with oxidative stress, such as cardiovascular diseases $(11,12)$, neurodegenerative diseases (13), and cancers (14). Despite this, clinical trials have failed to establish any preventive effects of $\alpha$-Toco on cardiovascular diseases and cancer (15-17). Recently, however, it was reported that dietary administration of $\delta$ - and $\gamma$-TP inhibited tumorigenesis in an animal model of estrogen receptor (ER)-positive but not human epidermal growth factor receptor (HER-2)-positive breast cancer (18). Parallel to this observation, a number of studies have shown that vitamin E, as an antioxidant, may interfere with the pharmacological action of some anticancer drugs, which rely on reactive oxygen species production as part of their mechanism of action (19). This is the case for the anticancer drug tamoxifen and other selective antiestrogen-binding site (AEBS) ligands such as tesmilifene, developed for the treatment of breast, lung, and prostate cancers (20-22), all of which have their antiproliferative and proapototic activities blocked by $\alpha$-TP (23-27). $\alpha$-TP has also been shown to inhibit the lipoperoxydation of cholesterol,
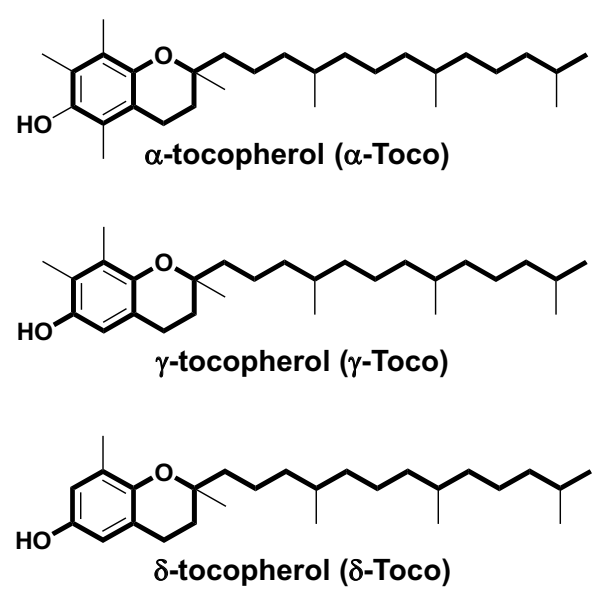

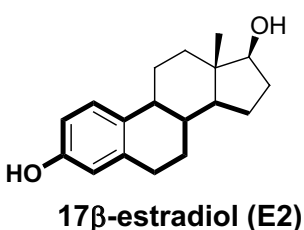

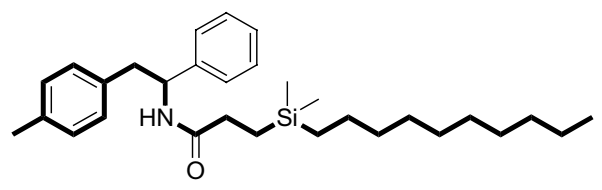

Sah 58-035<smiles>CC(C)=CCCC(C)=CCCC(C)=CCCC1CCC2C(C)=C(O)C(C)=C(C)C2O1</smiles><smiles>CC(C)=CCCC(C)=CCCC(C)=CCCC1CCc2cc(O)c(C)c(C)c2O1</smiles><smiles>CC(C)=CCC/C(C)=C/CC/C(C)=C/CCC1CCc2cc(O)cc(C)c2O1</smiles><smiles>CCCCN(C)C(=O)CCCCCCCCCC1Cc2cc(O)ccc2C2CCC3(C)C(O)CCC3C12</smiles><smiles>CC(C)(C)Sc1cc(C(C)(C)C)c(O)c(C(C)(C)C)c1</smiles><smiles>Cc1cc(C(C)(C)C)c(O)c(C(C)(C)C(Br)Br)c1</smiles>

FIGURE 1 | Chemical structures of $\alpha$-, $\gamma$-, and $\delta$-tocopherol; $\alpha$-, $\gamma$-, and $\delta$-tocotrienol; $17 \beta$-estradiol; ICI 164,384; Sah 58-035; probucol; and butylated hydroxytoluene (BHT). Boldface type indicates the part of the molecules that are superimposable. 
blocking the production of the prodifferentiation and proapototic cholesterol-5,6-epoxides that have been identified as mediators of tamoxifen activity in breast cancer cells $(21,26,28,29)$. These data suggest that the intake of $\alpha$-TP during prophylactic or curative treatment could impair the clinical outcome of patients treated with tamoxifen. In fact, many patients undergoing breast cancer treatment are known to take antioxidant dietary supplements, which may have a negative impact on their clinical outcome (30).

Tocopherol and TT contain structural determinants such as a phenol group, a cyclic structure, and long hydrophobic side chains that make them possible ligands for ERs (31). One study reported them to be weak modulators of ER $\beta$ but curiously found that they did not affect $E R \alpha$ activity (32). ERs are nuclear receptors (NRs) that mediate the biological effects of estrogens. They influence many physiological processes, including not only reproductive functions but also hormone-dependent cancers, cardiovascular health, bone integrity, immunity, cognition, and behavior $(33,34)$. The present study aimed to reevaluate the impact of TP and TT on ER-dependent transcriptional activity and breast cancer cell proliferation.

\section{MATERIALS AND METHODS}

\section{Chemicals}

$\left[{ }^{3} \mathrm{H}\right]-17 \beta$-estradiol and $\left[{ }^{14} \mathrm{C}\right]-\mathrm{HMG}-\mathrm{CoA}$ were purchased from GE Healthcare (UK). ICI 182,780 was from Tocris (UK). TPs and TTs were from Merk-Millipore (USA) or were kindly provided by Dr. Abdul Gapor (Kuala Lumpur, Malaysia); other compounds and chemicals were from Sigma-Aldrich (USA). All solvents were from Prolabo (France).

\section{Synthesis of $\delta$-Tocopherylquinone}

A solution of gold III chloride $(0.28 \mathrm{~g}$; $0.92 \mathrm{mmol})$ dissolved in water $(1 \mathrm{ml})$ was added dropwise to a solution of $\delta$-Toco $(0.36 \mathrm{~g}$; $0.89 \mathrm{mmol})$ dissolved in ethanol $(9 \mathrm{ml})$. The mixture was stirred in the absence of light for $2 \mathrm{~h}$ at room temperature. The solution was then evaporated and the solid residue was resuspended in dichloromethane and filtered. The organic layer was washed three times with water, dried over magnesium sulfate, filtered, and evaporated to dryness. The orange oil was purified by reverse phase HPLC (Ultrasep ES $100 \mathrm{RP} 18,250 \times 8 \mathrm{~mm}, 6.0 \mu \mathrm{m}$, using acetonitrile for $10 \mathrm{~min}$, linear gradient of $100 \%$ acetonitrile to $100 \% \mathrm{MeOH}$ for $60 \mathrm{~min}$; flow rate $=1 \mathrm{ml} / \mathrm{min}$ ) and yielded a pure colorless oil product. MS: DCI $\left(\mathrm{NH}_{3}\right), \mathrm{MH}^{+}=419$; TLC Silica: $\mathrm{Rf}$ $\left(\mathrm{CHCl}_{3}\right): 0.18$; HPLC, Rt $=30 \mathrm{~min}$; UV: $\lambda_{\max }=260 \mathrm{~nm}$.

\section{Molecular Structure Analysis}

Computational chemical calculations were performed on a Silicon Graphics Indigo workstation using Insight II version 2000 (Accelrys, San Diego, CA, USA). Minimal energy conformations were calculated using the Discover module (2.9.7/95.0/3.0.0) with the CVFF force field. Van der Waals volumes and van der Waals volume intersections were determined using the SearchCompare module version 95.0 (Accelrys). We first compared the structure of $\alpha$-tocopherol ( $\delta$-TP) with that of ICI 164,384 . Superimposition was carried out between the energy minimized structure of $\alpha$-TP and ICI 164,384 in the conformations adopted in the crystallographic structure of ER $\beta$-ICI 164,384 (35) (Protein Data Bank 1HJ1). Superimposition was conducted using the diphenylethane part of $\alpha$-TP that was superimposed carbon to carbon onto the steroidal backbone of ICI 164,384. The van der Waals volumes of $\alpha$-TP and ICI 164,384 were also compared and the percentage of superimposition was calculated by measuring the ratio of the intersection of the van der Waals volume of ICI 164,384 with the van der Waals volume of $\alpha$-TP.

\section{Estrogen Receptor-Binding Assay}

Estrogen receptor-binding experiments with $\left[{ }^{3} \mathrm{H}\right] 17 \beta$-estradiol were conducted exactly as reported in a previously published paper using extracts from Cos-7 cells transfected with expression vectors encoding human $\operatorname{ER} \alpha$ and $\operatorname{ER} \beta$ (36).

\section{Molecular Modeling with Estrogen Receptors}

$\delta$-tocotrienol $(\delta-\mathrm{TT})$, generated as described above, was prepositioned in the 4-hydroxytamoxifen (OHT)-ER $\alpha$ ligand-binding domain (LBD) crystal structure (Protein Data Bank 3ERT) (37) using the Search-Compare module of Insight II (Accelrys). The superimposition of OHT and $\delta$-TT was carried out as described previously (38). Once prepositioned, OHT was unmerged from the OHT-ER $\alpha$ complex and deleted, and $\delta$-TT was then merged to the receptor. The resulting complex was submitted to energy minimization using 250 steps of the steepest descent followed by a conjugated gradient until the root mean square gradient was $<0.001 \mathrm{kcal} / \mathrm{mol} / \AA$. A distant-dependent dielectric term $(\epsilon=r)$ and a 20 -Å non-bonded cutoff distance were chosen, whereas the hydrogen bond involved in the conformation of the $\alpha$ helices was preserved by applying a generic distance constraint between the backbone oxygen atoms of residue $i$ and the backbone nitrogen atoms of residue $i+4$, excluding prolines. This was performed using the Discover calculation engine with the CVFF force field (Insight II version 2000.1; Accelrys). The minimized coordinates of the receptor were then used as the starting point for $100 \mathrm{ps}$ at $300 \mathrm{k}$ using the Verlet algorithm whereas the constraint used during minimization was maintained. The resulting conformation was then further minimized using 250 steps of the steepest descent followed by a conjugated gradient until the root mean square gradient was $<0.001 \mathrm{kcal} / \mathrm{mol} / \AA$.

\section{Reporter Cell Lines and Luciferase Assay}

MELN cells were established by transfecting ER(+) MCF-7 cells with the ERE- $\beta$-globin-tk-Luc-SV-Neo plasmid (36). HELN cells were generated by transfection of ER(-) HeLa cells with this plasmid. The HELN-ER $\alpha$, HELN-ER $\beta$, HELN- $\Delta$ AB-ER $\alpha$, and HELN- $\triangle \mathrm{AB}-\mathrm{ER} \beta$ cell lines then underwent a second transfection with the corresponding pSG5-puro plasmids (pSG5-ER $\alpha$-puro, pSG5-ER $\beta$-puro, pSG5- $\Delta$ AB-ER $\alpha$-puro, and pSG5- $\Delta$ AB-ER $\beta$ puro, respectively) and expressed wild-type or mutated $\mathrm{ER} \alpha$ or $\operatorname{ER} \beta(39,40)$. Mutated $\operatorname{ER} \alpha$ or $\operatorname{ER} \beta$ have been deleted for the $\mathrm{AB}$ domain which possesses a ligand-independent activation function (AF1). Comparison of the activities toward $h E R \alpha$ and hER $\beta$ with the truncated $\Delta \mathrm{AB}-\mathrm{ER} \alpha$ and $\Delta \mathrm{AB}-\mathrm{ER} \beta$ provides a powerful model to identify partial ER agonists (requiring 
ligand-independent AF-1 to induce maximal ER activation). MELN and HELN cells expressed luciferase in an estrogendependent manner. Cells were grown routinely in DMEM growth medium supplemented with 5\% FBS (Gibco BRL, Life Technologies, Cergy pontoise, France). Cells were incubated at $37^{\circ} \mathrm{C}$ in a humidified $5 \% \mathrm{CO}_{2}$ incubator. For experiments, cells were grown for 5 days in phenol red-free medium, containing $6 \%$ dextran-coated charcoal-treated FCS (DCC-FCS) with penicillin-streptomycin. Medium was changed after 2 days. On day 5, cells were treated or not with the compounds, which were dissolved in ethanol. For each condition, $15 \times 10^{3}$ cells were seeded per well in 12-well plates and treated, as described above, for $8 \mathrm{~h}$ in a final volume of $0.5 \mathrm{ml}$. At the end of the treatment, cells were washed with PBS and lysed in $150 \mu \mathrm{l}$ lysis buffer (Promega, Charbonnières, France). Luciferase activity was measured using the luciferase assay reagent (Promega), according to the manufacturer's instructions. Protein concentrations were measured using the Bradford technique (41) to normalize the luciferase activity data. For each condition, average luciferase activity was calculated from the data of three independent wells.

\section{Cell Extracts and Western Blots}

MCF-7 cells were grown in 12-well plates and treated as indicated, then washed with PBS, and collected by centrifugation. Total cell lysates were prepared by resuspending the cells from each well in $100 \mu \mathrm{l}$ lysis buffer $(50 \mathrm{mM}$ Tris $\mathrm{pH} 6.8,2 \%$ SDS, $5 \%$ glycerol, 2 mM EDTA, 1.25\% $\beta$-mercaptoethanol, 0.004\% Bromophenol blue). Samples were boiled for $20 \mathrm{~min}$ at $95^{\circ} \mathrm{C}$ and cleared by centrifugation at $12,000 \times g$ for $10 \mathrm{~min}$. Protein concentration was determined by the Amido schwartz assay when samples contained SDS. Samples were subjected to PAGE on a $10 \%$ SDS-polyacrylamide gel in $25 \mathrm{mM}$ Tris- $\mathrm{HCl}, 200 \mathrm{mM}$ glycine, $\mathrm{pH} 8.3,0.1 \%$ SDS, and proteins were then transferred onto a nitrocellulose membrane. Western blot analysis was performed as previously described (42) using rabbit polyclonal ER $\alpha$ antibodies diluted to $1 \mu \mathrm{g} / \mathrm{ml}$ (HC20 or H-184 Santa Cruz Biotechnology, Inc.) and the mouse antihuman glyceraldehyde 3-phosphate dehydrogenase (1:1,000). Visualization was achieved with an Enhanced Chemiluminescence Plus kit (Perkin Elmer) and luminescence was measured by either autoradiography or using a PhosphorImager (Storm 840; GE Healthcare).

\section{Cell Proliferation Assay}

MCF-7 (ER(+)), T47D (ER(+)), and MDA-MB-231 (ER(-)) cell lines were from ATCC. Cell lines were maintained at $37^{\circ} \mathrm{C}$ in a humidified incubator in a $5 \% \mathrm{CO}_{2}$-enriched atmosphere in T-75 flasks. MCF-7, T47D, and MDA-MB-231 cells were grown routinely in phenol red RPMI 1640 medium supplemented with 5\% FBS (Gibco BRL, Life Technologies, Cergy Pontoise, France) and with penicillin-streptomycin. Cells were grown for $24 \mathrm{~h}$ before treatment in phenol red-free medium containing 5\% DCC-FCS. Cells were seeded into 96 -well plates at 2000 cells/well. Treatment media $(150 \mu \mathrm{l} /$ well $)$ was added on the following day and replaced at 48-h intervals until the end of the experiment. Cell density was measured via the sulforhodamine B method (43) after 0, 2, 4,6 , and 8 days. The absorbance of SRB was measured directly at
$490 \mathrm{~nm}$ in the 96 -well plates using a multiskan ${ }^{\circledR}$ multisoft reader from Labsystem.

\section{Determination of HMG-CoA Reductase Activity in Cell Extracts}

The microsomal fraction of MCF-7, T47D, and MDA-MB-231 cells was prepared as previously described (44). HMGR activity was determined using the procedure first described by Brown et al. (45): $100 \mu \mathrm{g}$ of microsomal protein was suspended in $0.1 \mathrm{M}$ potassium phosphate buffer $\mathrm{pH} 7.5$ containing $20 \mathrm{mM}$ glucose-6-phosphate, $2.5 \mathrm{mM} \mathrm{NADP}{ }^{+}, 1$ unit of glucose6-phosphate dehydrogenase, $5 \mathrm{mM}$ dithiothreitol and $0.2 \mu \mathrm{Ci}$ $\left[{ }^{14} \mathrm{C}\right]-\mathrm{HMG}-\mathrm{CoA}$. The reaction was stopped after $3 \mathrm{~h}$ by the addition of $25 \mu \mathrm{l} 6 \mathrm{~N} \mathrm{HCl}$. Mevalonate was converted to lactone by standing at $37^{\circ} \mathrm{C}$ for $30 \mathrm{~min}$, then extracted into $5 \mathrm{ml}$ ethyl acetate, and brought to dryness by evaporative centrifugation. The sample was dissolved in $50 \mu \mathrm{l}$ ethyl acetate and fractionated by silica thin-layer chromatography with toluene:acetone $(1 / 1)$. Mevalonolactone was identified by comigration with authentic mevalonolactone visualized by iodine vapor staining and quantified storm analysis.

\section{Statistical Analysis}

Values are the mean \pm SEM of three independent experiments, each carried out in duplicate. Statistical analysis was made by twoway ANOVA, where appropriate (Prism 6, GraphPad Software, Inc., San Diego, CA, USA). ${ }^{\star *} P<0.001 ;{ }^{* *} P<0.05 ;{ }^{\star} P<0.01$; ns: not significant.

\section{RESULTS}

\section{TP and TT Share Structural Similarities with Estrogen Receptor Ligands}

In previous studies, we used a pharmacophore approach to identify new targets for known drugs to explain some of their pharmacological properties $(36,38,42,46-48)$. We applied this approach to vitamin E compounds. The secondary structures of TPs, TTs, 17 $\beta$-estradiol, ICI-164,384, Sah 58-035, probucol, and butylated hydroxytoluene (BHT) are shown in Figure 1. Tocols are phenolic compounds with a long hydrophobic side chain that are similar to ER ligands, such as ICI 164,384 or Sah 58-035, when drawn in a two-dimensional representation (36) (Figure 2A). This similarity was confirmed by comparison of the active structure of ICI 164,384 cocrystallized with ER- $\beta$ with a minimal energy conformation of $\alpha$-TP in a three-dimensional representation (Figure 2A). The van der Waals volumes of $\alpha$-TP and ICI 164,384 were $406.57 \AA$ and $469 \AA$, respectively (Figure 2A). Superimposition of the compounds is shown in Figure 2A and reveals that ICI 164,384 and $\alpha$-TP share a common volume of $254.07 \AA$, which represents $63 \%$ of the van der Waals volume of $\alpha$-TP. The hydrophobic side chain of both compounds gives a perfect superimposition, with the exception of the ultimate ethyl group of the side chain of ICI 164,384. This shows that the molecular volume defined by $\alpha$-TP lies within the ligand-accessible volume of the ER and that the orientation of 


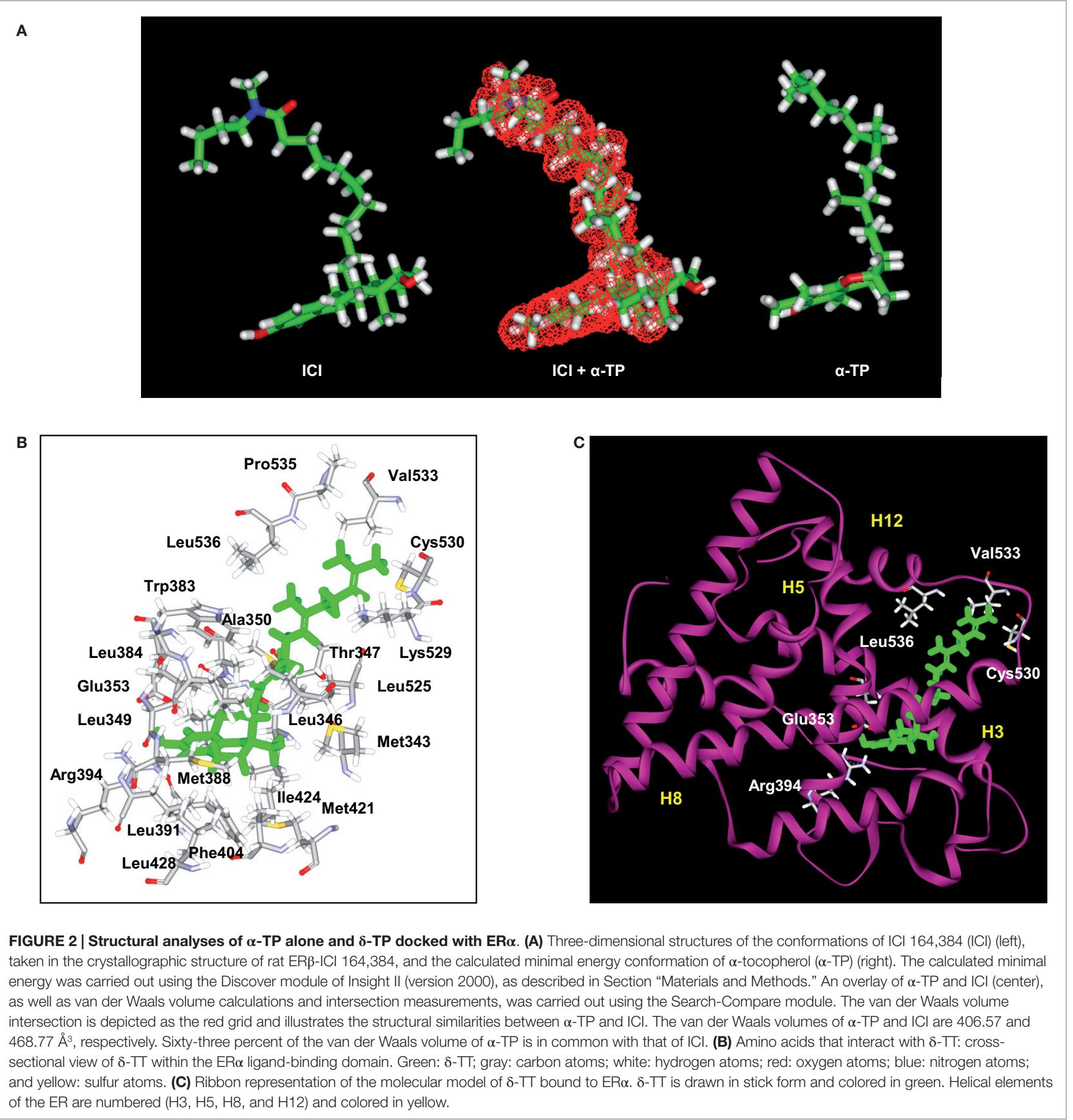

the hydrophobic side chain of tocols corresponds to that of the aliphatic site chain of ICI 164,384 and Sah 58-035. Altogether, these data are consistent with a direct interaction of $\alpha$-TP with the ER.

\section{Tocols Are Ligands for ER $\alpha$ and ER $\beta$}

We next investigated whether $\alpha_{-}^{-}, \gamma_{-}^{-}$, and $\delta$-TPs and -TTs interact with the two human ER subtypes (ER $\alpha$ and $\operatorname{ER} \beta)$ by conducting competition experiments with tritiated $17 \beta$-estradiol $\left[{ }^{3} \mathrm{H}\right]-\mathrm{E} 2$ (Table 1). The tocols bound to ER $\alpha$ and $E R \beta$ with the following order of affinity (highest to lowest): $\delta$-tocols $>\gamma$-tocols $>\alpha$-tocols. Thus, increasing the hindrance of the phenol group by increasing the number of methyl groups led to a decrease in affinity for both ERs. The oxidized product of $\delta$-TP, $\delta$-tocopherylquinone ( $\delta$-TPQuin), did not bind to the ERs, highlighting the importance of the phenol group in ER interaction (Table 1). The phenolic 
TABLE 1 | ER binding experiments.

\begin{tabular}{lcc}
\hline & ER $\boldsymbol{\alpha}\left(\mathbf{I C}_{50}\right)$ & ER $\boldsymbol{\beta}\left(\mathbf{I C}_{50}\right)$ \\
\hline$\alpha$-TP & $453 \pm 30 \mu \mathrm{M}$ & $431 \pm 21 \mu \mathrm{M}$ \\
$\boldsymbol{\gamma}$-TP & $227 \pm 28 \mu \mathrm{M}$ & $215 \pm 16 \mu \mathrm{M}$ \\
$\delta$-TP & $118 \pm 15 \mu \mathrm{M}$ & $98 \pm 12 \mu \mathrm{M}$ \\
$\alpha-T T$ & $412 \pm 22 \mu \mathrm{M}$ & $388 \pm 32 \mu \mathrm{M}$ \\
$\gamma$-TT & $203 \pm 25 \mu \mathrm{M}$ & $205 \pm 18 \mu \mathrm{M}$ \\
$\delta$-TT & $96 \pm 6 \mu \mathrm{M}$ & $91 \pm 7 \mu \mathrm{M}$ \\
Probucol & N.M. & N.M. \\
BHT & N.M. & N.M. \\
$\delta$-TPQuin & N.M. & N.M.
\end{tabular}

Extracts from cos-7 cells transfected with expression vectors encoding human ER $\alpha$ and $E R \beta$ were incubated with $2 \mathrm{nM}\left[{ }^{3} \mathrm{H}\right]$-E2 and different concentration of tocols ranging from $1 \mu \mathrm{M}$ to $1 \mathrm{mM}$. $/ C_{50}$ values were determined using the iterative curvefitting program GraphPad prism version 5 (GraphPad Software). N.M., not measurable.

antioxidants, BHT, and probucol, had no detectable affinity, probably because of the presence of two bulky tertiobutyl substituents adjacent to the hydroxyphenol group and because of the absence of a hydrophobic side chain. Interestingly, the $\mathrm{IC}_{50}$ values obtained for the TP corresponded to the concentrations they were tested on cell lines in vitro $(100-500 \mu \mathrm{M})(23,24,26,27,49-53)$. These data show that tocols are ligands for both $\mathrm{ER} \alpha$ and $\mathrm{ER} \beta$.

\section{Molecular Modeling of the $\delta$-TP-ER $\alpha$ Complex}

The ability of tocols to interact with ERs raised the question of the molecular consequences of this interaction. In the absence of a crystal structure of the tocol-ER complex, we investigated this issue through molecular modeling. Figures 2B,C show the chemical interactions between $\delta$-TP and ER $\alpha$. Interestingly, the phenol group of $\delta$-TP inhabited the LBD in a similar fashion as E2: the hydroxyl group interacted with Glu-353 and Arg-394. The phenyl part of the chromanol group produced a T-shaped interaction with the phenyl side chain of Phe-404 and had van der Waals contacts with the methyl groups of Leu-391 and Leu384. These data show that the chromanol backbone of $\delta$-TP can occupy the same cavity as E2 or diethylstilbestrol $(37,54)$. The side chain of $\delta$-TP protruded into the $11 \beta$ cavity of the LBD of $\mathrm{ER} \alpha$ and produced multiple van der Waals interactions with hydrophobic amino acids, such as Ala-350, Leu-525, and Trp383. The upper part of the side chain interacted with Val-533, Leu-536, Leu-539, Leu-540, and Met-543. These latter amino acids belong to helix H12, thus showing an interaction between the upper part of the side chain of $\delta$-TP and helix H12 in this model, as was observed for Sah 58-035 (36). $\delta$-TP established a van der Waals interaction with Met- 421 but no interactions were detected with Leu-384, suggesting that they might not discriminate between the two ER subtypes, which are consistent with binding experiments. The docking of the more hindered $\alpha$-tocols showed a loss of the interaction of the hydroxy phenolic group with Glu-353 and Arg-394, explaining their weaker affinity compared to $\delta$-tocols. These data illustrate that tocols are accommodated well within the ER binding site in a similar way as that previously established with Sah 58-035 and auraptene
$(36,42)$. This suggests that tocols can act as modulators of ERs rather than pure agonists.

\section{Tocols Are Partial Agonists for ER-Mediated Transcription}

The next set of experiments were designed to investigate whether tocols can modulate ER-dependent transcription, using MCF-7 cells stably transfected with a plasmid encoding an estrogenresponsive promoter fused to the luciferase gene (MELN cells) (36). Figure $\mathbf{3 A}$ shows that all the tocols tested stimulated luciferase transcription, with the best response obtained using $500 \mu \mathrm{M} \delta$-TP and $\delta$-TT, which resulted in 76.5 and $86.6 \%$ of the maximal ER-dependent response (taken as that obtained from treatment with $10 \mathrm{nM} \mathrm{E2),} \mathrm{respectively.} \mathrm{Tocol-induced}$ ER-dependent transcriptional activity was blocked in the presence of the ER antagonist ICI 164,384 (Figure 3B). As expected, compounds that were previously determined as non-ER ligands, such as $\delta$-tocopherylquinone ( $\delta$-TPQuin), BHT, and probucol, did not stimulate the expression of luciferase (Figure 3B). We next established that $\delta$-TP- and $\delta$-TT-bound ER $\alpha$ was not degraded as was observed for ER $\alpha$ bound to E2 (Figure 3C). Thus, the effect of $\delta$-TP and $\delta$-TT on ER protein stability is similar to that of selective ER modulators, suggesting that tocols are not pure estrogens. $\delta$-TP and $\delta$-TT were also shown to activate ER-dependent luciferase activity through both $\mathrm{ER} \alpha$ and ER $\beta$, using HELN cells (HeLa cells transfected with the same plasmid as MELN cells, which encodes an estrogen-responsive promoter fused to the luciferase gene) (Figure 3D). In order to further characterize the agonistic properties of the $\delta$-tocols, the HELN-ER $\alpha$ and -ER $\beta$ cell lines were used alongside the HELN- $\triangle \mathrm{AB}-\mathrm{ER} \alpha$ and HELN- $\triangle \mathrm{AB}-\mathrm{ER} \beta$ cell lines in which the $\mathrm{N}$-terminal AF1 domain of the ERs (responsible for the majority of ER transactivation activity) is deleted (40). We observed that $\mathrm{ER} \alpha$-mediated transcriptional activation induced by the $\delta$-tocols was strongly altered in the absence of the AF1 domain, whereas the loss of this domain did not significantly affect ER $\beta$-mediated transcriptional activation induced by the $\delta$-tocols (Figure 3D). To determine whether $\delta$-TP and $\delta$-TT can modulate the expression of endogenous E2-regulated genes as well as reporter genes, the expression of the progesterone receptor gene (PR), trefoil factor-1 (TFF1, Ps2), and transforming growth factor alpha (TGF $\alpha$ ) was measured by quantitative RT-PCR in MCF-7 cells. Treatment of MCF-7 cells with $\delta$-TP stimulated the transcription of TGF $\alpha$ (1.4-fold increase), PR (1.8-fold), and Ps2 (1.9-fold) (Figure 3E). The treatment of MCF-7 cells with $\delta$-TT stimulated the transcription of TGF $\alpha$ (1.1-fold), PR (1.6-fold), and Ps2 (twofold). These results confirm that $\delta$-TP and $\delta$-TT can activate the transcription of endogenous genes that are known to be under the control of ER $\alpha$.

\section{The Effect of $\delta$-Tocols on the Proliferation of ER(+) and ER(-) Breast Cancer Cells}

To investigate the effects of $\delta$-TP and $\delta$-TT on cell growth, $\mathrm{ER}(+)$ human BC cell lines (MCF-7 and T47D) and an ER(-) BC cell line (MDA-MB-231) were used. As shown in Figure 4A, $\delta$-TP 

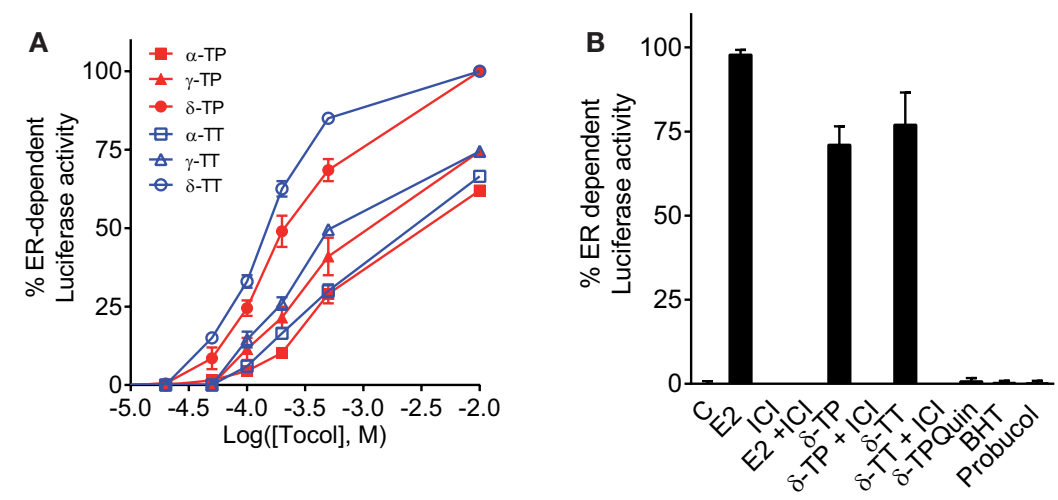

C

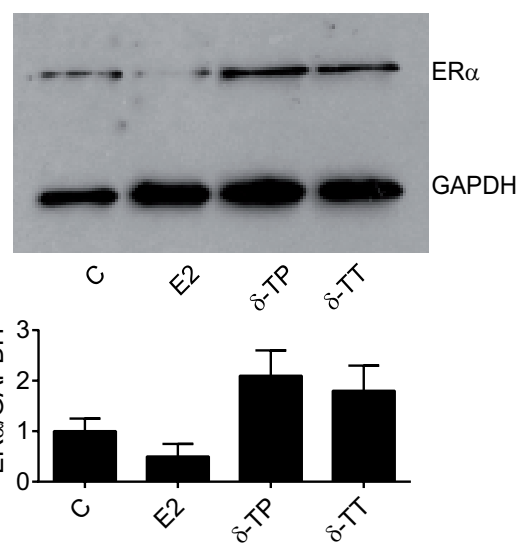

$\mathbf{E}$

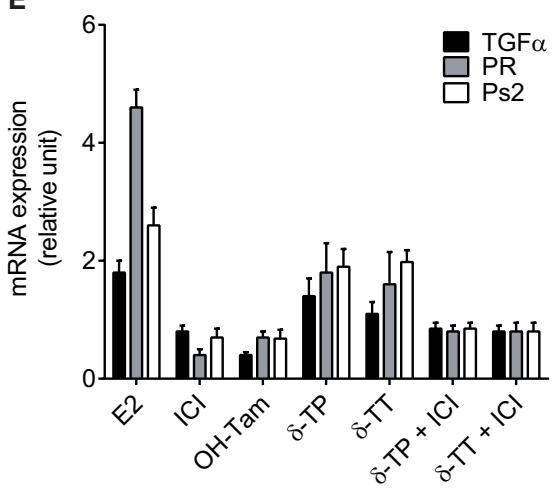

FIGURE 3 | Measurement of estrogenicity of tocols in vitro. (A) Dose-response curve of the effect of tocols on MCF-7 cells stably transfected with the ERE- $\beta$-globin-tk-Luc plasmid (MELN cells). Results are represented as the percentage of ER-dependent $\alpha$-, $\gamma-$, and $\delta$-TP and $\alpha-, \gamma-$, and $\delta$-TT luciferase activity obtained with $10 \mathrm{nM}$ E2 and increasing concentrations of tocols ranging from 10 to $500 \mu \mathrm{M}$. (B) ER-dependent transcriptional modulatory activity of $500 \mu \mathrm{M} \delta$-TP, $\delta$-TT, $\delta$-Tocopherolquinone ( $\delta$-TPQuin), butylated hydroxytoluene (BHT), and probucol in MELN cells. Cells were incubated with either $10 \mathrm{nM} 17 \beta$ estradiol (E2), $500 \mu \mathrm{M} \delta$-TP or $500 \mu \mathrm{M} \delta$-TT alone or in combination with $1 \mu \mathrm{M}$ pure antiestrogen ICI 164,384 (ICI) or were incubated with $500 \mu \mathrm{M} \delta$-TPQuin, $500 \mu \mathrm{M}$ BHT or $500 \mu \mathrm{M}$ probucol and assayed for luciferase activity. Data shown are the mean values \pm SEM from three independent experiments. (C) $\delta$-TP or $\delta$ - $T T$ stabilized ER- $\alpha$ in MCF-7 cells. MCF-7 cells were cultured as described in Section "Materials and Methods" and treated with either solvent vehicle (EtOH), $100 \mathrm{nM}$ E2, $500 \mu \mathrm{M} \delta$-TP or $500 \mu \mathrm{M} \delta$ - TT for $3 \mathrm{~h}$. MCF-7 extracts were analyzed for the presence of ER $\alpha$ by western blotting using GAPDH as a control. Visualization was achieved with an Enhanced Chemiluminescence Plus kit and fluorescence was measured by either autoradiography or using a Phosphorlmager. The western blot shown is representative of three independent experiments. The ratio of ER $\alpha$ to GAPDH levels in each experiment was determined densitometrically and normalized to control value (taken to be 1). (D) Effect of $\delta$-tocols on estrogen response element-dependent luciferase activity in HELN cells, which are HELA cells transfected with either fully functional $E R \alpha$ or $E R \beta$ or their mutated versions containing a deletion the AB domain $(\Delta \mathrm{AB})$. Cells were incubated with $10 \mathrm{nM} 17 \beta$ estradiol (E2), $500 \mu \mathrm{M} \delta$-TP or $500 \mu \mathrm{M} \delta$-TT alone or in combination with $1 \mu \mathrm{M}$ pure antiestrogen ICI 164,384 (ICI) and assayed for luciferase activity. Data shown are the mean values \pm SEM from three independent experiments. (E) $\delta$-Tocols modulate the induction of endogenous genes under the control of ER. Cells were treated with solvent vehicle, $10 \mathrm{nM} \mathrm{E2}, 1 \mu \mathrm{M} \mathrm{ICl}, 1 \mu \mathrm{M} \mathrm{OH}$-Tam. Cells were treated with $500 \mu \mathrm{M} \delta$-tocols in the presence or in the absence of ICl. The relative expression of TGF $\alpha$, PR, and Ps2 (TFF1) after $16 \mathrm{~h}$ was analyzed by quantitative RT-PCR. Data shown are the mean values \pm SEM from three independent experiments.

$(500 \mu \mathrm{M})$ induced a significant stimulation of MCF-7 and T47D cell proliferation over a 6-day period, albeit to a lesser extent than E2 (10 nM), and had no impact on ER(-) MDA-MB-231 cells. Both $\delta$-TP- and E2-induced stimulation of proliferation was blocked by the ER antagonist ICI 164,384, consistent with an ER-mediated event (Figure 4A). In contrast, $\delta$-TT inhibited the proliferation of cells, and these effects were amplified in the presence of E2 or ICI 164,384. Only cotreatment of cells with mevalonolactone $(\mathrm{M})$ protected all three cell lines from the inhibitory effects of $\delta$-TT (Figure 4A). Mevalonolactone is known to reverse the mevalonate-isoprenoide pathway when HMGR is inhibited suggesting that $\delta$-TT inhibited HMGR in BC cells as observed in other cell lines $(2,55-58)$. We found a similar effect using when cells where treated with lovastatin, a prototypical inhibitor of HMGR, and as expected, the inhibition of cell proliferation was reversed by mevalonolactone (Figure 4A). These differential actions of $\delta$-TP and $\delta$-TT are consistent with an inhibition of HMGR activity that was observed downstream of $\delta$-TT but not $\delta$-TP in these cell lines (Figure 4B). Altogether, these data show that $\delta$-TP stimulates cell proliferation in a similar way to that of ER agonists while $\delta$-TT inhibits cell growth, consistent with its capacity to down regulate HMGR. 
MCF-7 (ER+) $\square$ T47D (ER+) $\square$ MDA-MB-231(ER-)

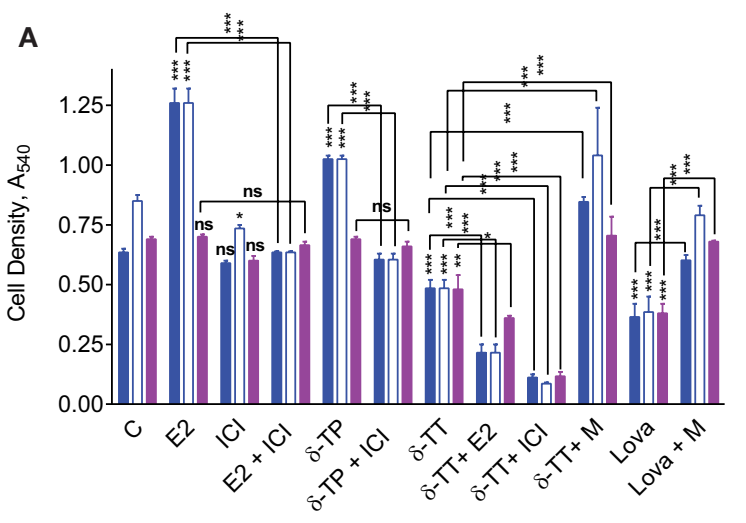

B

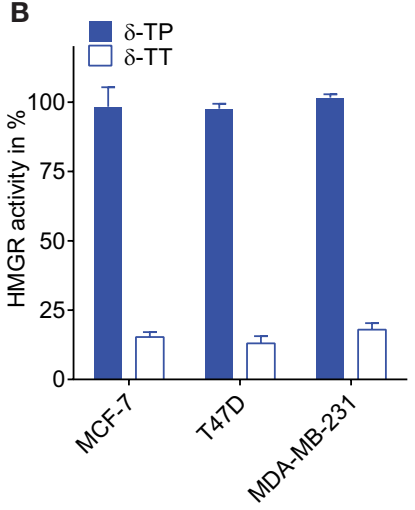

FIGURE 4 | Effect of tocol on ER(+) and ER(-) BC cell proliferation and HMG-CoA reductase activity. (A) Effect of $\delta$-tocols on estrogen and non-estrogenregulated growth of MCF-7, T47D, and MDA-MB-231 cells. Cells were treated with solvent vehicle (C), $1 \mathrm{nM} 17 \beta$ estradiol (E2), or $500 \mu \mathrm{M} \delta$-TP in the presence or absence of $1 \mu \mathrm{M} \mathrm{ICl}$. Alternatively, cells were treated with $500 \mu \mathrm{M} \delta$ - TT in the presence or absence of $100 \mathrm{nM} \mathrm{E2,} 1 \mu \mathrm{M}$ ICl, or $5 \mathrm{mM}$ mevalonolactone (M). Cells were also treated with $30 \mu \mathrm{M}$ lovastatin (Lova) in the presence or absence of $5 \mathrm{mM} \mathrm{M}$, as described in Section "Materials and Methods." Values are shown as means and vertical bars represent SEM. The data were analyzed by two-way ANOVA, followed by Bonferroni post hoc test. ${ }^{\star \star \star} P<0.001$, ${ }^{\star \star} P<0.01$, and ${ }^{\star} P<0.05$ in comparison with control or bare-linked specific control. Ns: not significant. (B) Effect of $\delta$ - $\Pi$ on hydroxymethylglutaryl coenzyme A reductase (HMGR) activity in MCF-7, T47D, and MDA-MB-231 cells. Cells were treated with $500 \mu \mathrm{M} \delta$ - $T$ or $\delta$-TP, as described in Section "Materials and Methods." Results are reported as the percentage of HMGR activity compared to solvent vehicle-treated cells. Data shown are the mean values \pm SEM from three independent experiments performed in triplicate.

\section{DISCUSSION}

In this paper, we report the identification of a new molecular target of vitamin E compounds that sheds light on their pharmacological potency and the potential risks related to their specific substructures. Using a ligand-structure based approach, we found that TPs and TTs are ER ligands and behave like partial agonists in ER-mediated transcriptional regulation of synthetic and endogenous genes. Therefore, they are phytoestrogens. Consistent with this data, vitamin $\mathrm{E}$ has been previously reported to increase the expression of estrogenic markers in breast biopsies of patients (53). We found that both the effects of the tocol derivatives on transcription and their affinity for ER $\alpha$ decreased with the number of methyl groups present on the phenol ring of the compounds, the most potent phytoestrogens being $\delta$-TP and $\delta$-TT. These data emphasize the importance of the accessibility of the $\mathrm{OH}$ phenolic group in establishing a productive interaction with the Glu353 and Arg394 residues in ER $\alpha$. Molecular modeling studies suggested that the aliphatic side chain of tocols can occupy the $11 \beta$-cavity of the LBD, as observed for the side chains of steroidal and non-steroidal ER ligands $(59,60)$. The tocol side chain enables their interaction with helix $\mathrm{H} 12$ on the NR box-binding site (Figure 2B), consistent with an agonistic activity. The use of AF1 deletion mutants also demonstrated the requirement of the AF1 transactivation domain for $\delta$-tocol activity and revealed that they act differently than E2 on ER $\alpha$ since they do not induce receptor degradation upon binding. Other phenolic antioxidants, such as BHT or probucol, did not display any estrogenic effects, which supports the observation that the estrogenic action of $\delta$-TP was peculiar in its ER-binding activity. The presence of a bulky tertiobutyl group in the ortho position from the hydroxyl of the phenols in these compounds may explain this effect. Furthermore, the oxidated form of $\delta$ TP had no estrogenic activity as a consequence of its loss of affinity for binding to the ER. This established that ER binding and ER-dependent transcriptional stimulation of tocols are dependent upon their reduced form status.

It is noteworthy that $\delta$-tocols were found to stimulate TGF $\alpha$ expression in vitro in human breast cancer cells. TGF $\alpha$ can activate mitogenic pathways; so, this finding highlights the potential risk that these compounds could promote tumor growth. However, dietary administration of $\delta$-TP was shown to protect against $N$-methyl- $N$-nitrosourea hormone-dependent tumorigenesis in Sprague-Dawley rats (18); therefore, based on the present data, it is now important to determine whether this effect is observable in different rodent species because potential selective ER modulator activity has been shown to induce responses in animal models that are not seen in humans (61).

In this paper, we report that TPs and TTs are agonists for both ER subtypes. We show that $\delta$-TP stimulated the proliferation of ER-expressing cells, whereas TTs were potent inhibitors of cell proliferation irrespective of the cell's ER status. This difference in activity could have resulted from the capacity of TTs to downregulate HMGR activity since it was reversed through addition of mevalonolactone, demonstrating the importance of the inhibition of the isoprenoide-cholesterol pathway in this effect (Figure 4A). Based on these data, we established that it is possible to distinguish between the action of TPs and TTs since although both TPs and TTs displayed antioxidant and ER stimulatory activity, and only TTs displayed an antiproliferative activity. 
Altogether, these data have established that tocols are phytoestrogens and that their transcriptional modulation of ER must be taken into account to better understand their properties.

\section{AUTHOR CONTRIBUTIONS}

FK performed chemical, biochemical studies and analyzed data. PM performed biochemical studies and analyzed data; SC-S and $\mathrm{KB}$ performed biochemical and cellular experiments and analyzed the data; PB performed cellular experiments and analyzed

\section{REFERENCES}

1. Evans HM, Bishop KS. On the existence of a hitherto unrecognized dietary factor essential for reproduction. Science (1922) 56:650-1. doi:10.1126/ science.56.1458.650

2. Parker RA, Pearce BC, Clark RW, Gordon DA, Wright JJ. Tocotrienols regulate cholesterol production in mammalian cells by post-transcriptional suppression of 3-hydroxy-3-methylglutaryl-coenzyme A reductase. J Biol Chem (1993) 268:11230-8.

3. Agarwal MK, Agarwal ML, Athar M, Gupta S. Tocotrienol-rich fraction of palm oil activates $\mathrm{p} 53$, modulates $\mathrm{Bax} / \mathrm{Bcl} 2$ ratio and induces apoptosis independent of cell cycle association. Cell Cycle (2004) 3:205-11. doi:10.4161/ cc.3.2.637

4. Yano Y, Satoh H, Fukumoto K, Kumadaki I, Ichikawa T, Yamada K, et al. Induction of cytotoxicity in human lung adenocarcinoma cells by 6-O-carboxypropyl-alpha-tocotrienol, a redox-silent derivative of alpha-tocotrienol. Int J Cancer (2005) 115:839-46. doi:10.1002/ijc.20809

5. Ahn KS, Sethi G, Krishnan K, Aggarwal BB. Gamma-tocotrienol inhibits nuclear factor-kappaB signaling pathway through inhibition of receptor-interacting protein and TAK1 leading to suppression of antiapoptotic gene products and potentiation of apoptosis. J Biol Chem (2007) 282:809-20. doi:10.1074/jbc.M610028200

6. Aggarwal BB, Sundaram C, Prasad S, Kannappan R. Tocotrienols, the vitamin E of the 21st century: its potential against cancer and other chronic diseases. Biochem Pharmacol (2010) 80:1613-31. doi:10.1016/j.bcp.2010.07.043

7. Kiyose C, Muramatsu R, Kameyama Y, Ueda T, Igarashi O. Biodiscrimination of alpha-tocopherol stereoisomers in humans after oral administration. Am J Clin Nutr (1997) 65:785-9.

8. Ng MH, Choo YM, Ma AN, Chuah CH, Hashim MA. Separation of vitamin E (tocopherol, tocotrienol, and tocomonoenol) in palm oil. Lipids (2004) 39:1031-5. doi:10.1007/s11745-004-1327-y

9. Khallouki F, Haubner R, Ricarte I, Erben G, Klika K, Ulrich CM, et al. Identification of polyphenolic compounds in the flesh of Argan (Morocco) fruits. Food Chem (2015) 179:191-8. doi:10.1016/j. foodchem.2015.01.103

10. Donapaty S, Louis S, Horvath E, Kun J, Sebti SM, Malafa MP. RRR-alphatocopherol succinate down-regulates oncogenic Ras signaling. Mol Cancer Ther (2006) 5:309-16. doi:10.1158/1535-7163.MCT-05-0330

11. Manson JE, Gaziano JM, Jonas MA, Hennekens CH. Antioxidants and cardiovascular disease: a review. J Am Coll Nutr (1993) 12:426-32. doi:10.1080/ 07315724.1993.10718332

12. Kaul N, Devaraj S, Jialal I. Alpha-tocopherol and atherosclerosis. Exp Biol Med (Maywood) (2001) 226:5-12.

13. Behl C. Oestrogen as a neuroprotective hormone. Nat Rev Neurosci (2002) 3:433-42. doi:10.1038/nrn846

14. Albanes D, Heinonen OP, Huttunen JK, Taylor PR, Virtamo J, Edwards BK, et al. Effects of alpha-tocopherol and beta-carotene supplements on cancer incidence in the Alpha-Tocopherol Beta-Carotene Cancer Prevention Study. Am J Clin Nutr (1995) 62:1427S-30S.

15. Lonn E, Bosch J, Yusuf S, Sheridan P, Pogue J, Arnold JM, et al. Effects of long-term vitamin E supplementation on cardiovascular events and cancer: a randomized controlled trial. JAMA (2005) 293:1338-47. doi:10.1001/ jama.293.11.1338 the data; MP and SS-P designed the experiments, performed molecular modeling studies, analyzed the data, and wrote the paper.

\section{ACKNOWLEDGMENTS}

This study was supported by the Institut National de la Santé et de la Recherche Médicale, the Conseil Régional Midi-Pyrénées, and the Institut National du Cancer through the ResisTH network. FK was supported by a post-doctoral fellowship from the Institut National du Cancer.

16. Klein EA. Selenium and vitamin E: interesting biology and dashed hope. J Natl Cancer Inst (2009) 101:283-5. doi:10.1093/jnci/djp282

17. Lippman SM, Klein EA, Goodman PJ, Lucia MS, Thompson IM, Ford LG, et al. Effect of selenium and vitamin E on risk of prostate cancer and other cancers: the Selenium and Vitamin E Cancer Prevention Trial (SELECT). JAMA (2009) 301:39-51. doi:10.1001/jama.2008.864

18. Smolarek AK, So JY, Burgess B, Kong AN, Reuhl K, Lin Y, et al. Dietary administration of delta- and gamma-tocopherol inhibits tumorigenesis in the animal model of estrogen receptor-positive, but not HER-2 breast cancer. Cancer Prev Res (Phila) (2012) 5:1310-20. doi:10.1158/1940-6207.CAPR-12-0263

19. D'Andrea GM. Use of antioxidants during chemotherapy and radiotherapy should be avoided. CA Cancer J Clin (2005) 55:319-21. doi:10.3322/ canjclin.55.5.319

20. Poirot M, Silvente-Poirot S, Weichselbaum RR. Cholesterol metabolism and resistance to tamoxifen. Curr Opin Pharmacol (2012) 12:683-9. doi:10.1016/j. coph.2012.09.007

21. Silvente-Poirot S, Poirot M. Cancer. Cholesterol and cancer, in the balance. Science (2014) 343:1445-6. doi:10.1126/science.1252787

22. Dalenc F, Poirot M, Silvente-Poirot S. Dendrogenin A: a mammalian metabolite of cholesterol with tumor suppressor and neurostimulating properties. Curr Med Chem (2015) 22:3533-49. doi:10.2174/0929867322666150716114 912

23. Payre B, De Medina P, Boubekeur N, Mhamdi L, Bertrand-Michel J, Terce F, et al. Microsomal antiestrogen-binding site ligands induce growth control and differentiation of human breast cancer cells through the modulation of cholesterol metabolism. Mol Cancer Ther (2008) 7:3707-18. doi:10.1158/1535-7163. MCT-08-0507

24. de Medina P, Payre B, Boubekeur N, Bertrand-Michel J, Terce F, Silvente-Poirot $\mathrm{S}$, et al. Ligands of the antiestrogen-binding site induce active cell death and autophagy in human breast cancer cells through the modulation of cholesterol metabolism. Cell Death Differ (2009) 16:1372-84. doi:10.1038/cdd.2009.62

25. de Medina P, Silvente-Poirot S, Poirot M. Tamoxifen and AEBS ligands induced apoptosis and autophagy in breast cancer cells through the stimulation of sterol accumulation. Autophagy (2009) 5:1066-7. doi:10.4161/auto.5.7.9820

26. Segala G, De Medina P, Iuliano L, Zerbinati C, Paillasse MR, Noguer E, et al. 5,6-Epoxy-cholesterols contribute to the anticancer pharmacology of tamoxifen in breast cancer cells. Biochem Pharmacol (2013) 86:175-89. doi:10.1016/j. bcp.2013.02.031

27. Sola B, Poirot M, De Medina P, Bustany S, Marsaud V, Silvente-Poirot S, et al. Antiestrogen-binding site ligands induce autophagy in myeloma cells that proceeds through alteration of cholesterol metabolism. Oncotarget (2013) 4:911-22. doi:10.18632/oncotarget.1066

28. Silvente-Poirot S, Poirot M. Cholesterol epoxide hydrolase and cancer. Curr Opin Pharmacol (2012) 12:696-703. doi:10.1016/j.coph.2012.07.007

29. Poirot M, Silvente-Poirot S. Cholesterol-5,6-epoxides: chemistry, biochemistry, metabolic fate and cancer. Biochimie (2013) 95:622-31. doi:10.1016/j. biochi.2012.05.006

30. Greenlee H, Gammon MD, Abrahamson PE, Gaudet MM, Terry MB, Hershman DL, et al. Prevalence and predictors of antioxidant supplement use during breast cancer treatment: the Long Island Breast Cancer Study Project. Cancer (2009) 115:3271-82. doi:10.1002/cncr.24378

31. Anstead GM, Carlson KE, Katzenellenbogen JA. The estradiol pharmacophore: ligand structure-estrogen receptor binding affinity relationships and a 
model for the receptor binding site. Steroids (1997) 62:268-303. doi:10.1016/ S0039-128X(96)00242-5

32. Comitato R, Nesaretnam K, Leoni G, Ambra R, Canali R, Bolli A, et al. A novel mechanism of natural vitamin $\mathrm{E}$ tocotrienol activity: involvement of ERbeta signal transduction. Am J Physiol Endocrinol Metab (2009) 297:E427-37. doi:10.1152/ajpendo.00187.2009

33. Deroo BJ, Korach KS. Estrogen receptors and human disease. J Clin Invest (2006) 116:561-70. doi:10.1172/JCI27987

34. Heldring N, Pike A, Andersson S, Matthews J, Cheng G, Hartman J, et al. Estrogen receptors: how do they signal and what are their targets. Physiol Rev (2007) 87:905-31. doi:10.1152/physrev.00026.2006

35. Pike AC, Brzozowski AM, Walton J, Hubbard RE, Thorsell AG, Li YL, et al. Structural insights into the mode of action of a pure antiestrogen. Structure (2001) 9:145-53. doi:10.1016/S0969-2126(01)00568-8

36. de Medina P, Boubekeur N, Balaguer P, Favre G, Silvente-Poirot S, Poirot M. The prototypical inhibitor of cholesterol esterification, Sah 58-035 [3-[decyldimethylsilyl]-n-[2-(4-methylphenyl)-1-phenylethyl]propanamide], is an agonist of estrogen receptors. J Pharmacol Exp Ther (2006) 319:139-49. doi:10.1124/jpet.106.104349

37. Shiau AK, Barstad D, Loria PM, Cheng L, Kushner PJ, Agard DA, et al. The structural basis of estrogen receptor/coactivator recognition and the antagonism of this interaction by tamoxifen. Cell (1998) 95:927-37. doi:10.1016/ S0092-8674(00)81717-1

38. de Medina P, Payre BL, Bernad J, Bosser I, Pipy B, Silvente-Poirot S, et al. Tamoxifen is a potent inhibitor of cholesterol esterification and prevents the formation of foam cells. J Pharmacol Exp Ther (2004) 308:1165-73. doi:10.1124/jpet.103.060426

39. Escande A, Pillon A, Servant N, Cravedi JP, Larrea F, Muhn P, et al. Evaluation of ligand selectivity using reporter cell lines stably expressing estrogen receptor alpha or beta. Biochem Pharmacol (2006) 71:1459-69. doi:10.1016/j. bcp.2006.02.002

40. Molina-Molina JM, Escande A, Pillon A, Gomez E, Pakdel F, Cavailles V, et al. Profiling of benzophenone derivatives using fish and human estrogen receptor-specific in vitro bioassays. Toxicol Appl Pharmacol (2008) 232:384-95. doi:10.1016/j.taap.2008.07.017

41. Bradford MM. A rapid and sensitive method for the quantitation of microgram quantities of protein utilizing the principle of protein-dye binding. Anal Biochem (1976) 72:248-54. doi:10.1016/0003-2697(76)90527-3

42. de Medina P, Genovese S, Paillasse MR, Mazaheri M, Caze-Subra S, Bystricky $\mathrm{K}$, et al. Auraptene is an inhibitor of cholesterol esterification and a modulator of estrogen receptors. Mol Pharmacol (2010) 78:827-36. doi:10.1124/ mol.110.065250

43. Skehan P, Storeng R, Scudiero D, Monks A, Mcmahon J, Vistica D, et al. New colorimetric cytotoxicity assay for anticancer-drug screening. J Natl Cancer Inst (1990) 82:1107-12. doi:10.1093/jnci/82.13.1107

44. Kedjouar B, De Medina P, Oulad-Abdelghani M, Payre B, Silvente-Poirot S, Favre G, et al. Molecular characterization of the microsomal tamoxifen binding site. J Biol Chem (2004) 279:34048-61. doi:10.1074/jbc. M405230200

45. Brown MS, Goldstein JL. Suppression of 3-hydroxy-3-methylglutaryl coenzyme A reductase activity and inhibition of growth of human fibroblasts by 7-ketocholesterol. J Biol Chem (1974) 249:7306-14.

46. Kedjouar B, Daunes S, Vilner BJ, Bowen WD, Klaebe A, Faye JC, et al. Structural similitudes between cytotoxic antiestrogen-binding site (AEBS) ligands and cytotoxic sigma receptor ligands. Evidence for a relationship between cytotoxicity and affinity for AEBS or sigma-2 receptor but not for sigma-1 receptor. Biochem Pharmacol (1999) 58:1927-39. doi:10.1016/ S0006-2952(99)00285-3

47. Poirot M, De Medina P, Delarue F, Perie JJ, Klaebe A, Faye JC. Synthesis, binding and structure-affinity studies of new ligands for the microsomal anti-estrogen binding site (AEBS). Bioorg Med Chem (2000) 8:2007-16. doi:10.1016/S0968-0896(00)00119-X

48. de Medina P, Favre G, Poirot M. Multiple targeting by the antitumor drug tamoxifen: a structure-activity study. Curr Med Chem Anticancer Agents (2004) 4:491-508. doi:10.2174/1568011043352696

49. Gundimeda U, Chen ZH, Gopalakrishna R. Tamoxifen modulates protein kinase $\mathrm{C}$ via oxidative stress in estrogen receptor-negative breast cancer cells. J Biol Chem (1996) 271:13504-14. doi:10.1074/jbc.271.23.13504

50. Ferlini C, Scambia G, Marone M, Distefano M, Gaggini C, Ferrandina G, et al. Tamoxifen induces oxidative stress and apoptosis in oestrogen receptor-negative human cancer cell lines. Br J Cancer (1999) 79:257-63. doi:10.1038/ sj.bjc. 6690042

51. Mandlekar S, Hebbar V, Christov K, Kong AN. Pharmacodynamics of tamoxifen and its 4-hydroxy and $\mathrm{N}$-desmethyl metabolites: activation of caspases and induction of apoptosis in rat mammary tumors and in human breast cancer cell lines. Cancer Res (2000) 60:6601-6.

52. Mandlekar S, Yu R, Tan TH, Kong AN. Activation of caspase-3 and c-Jun $\mathrm{NH} 2$-terminal kinase-1 signaling pathways in tamoxifen-induced apoptosis of human breast cancer cells. Cancer Res (2000) 60:5995-6000.

53. Peralta EA, Brewer AT, Louis S, Dunnington GL. Vitamin E increases biomarkers of estrogen stimulation when taken with tamoxifen. J Surg Res (2009) 153:143-7. doi:10.1016/j.jss.2008.03.030

54. Brzozowski AM, Pike AC, Dauter Z, Hubbard RE, Bonn T, Engstrom O, et al. Molecular basis of agonism and antagonism in the oestrogen receptor. Nature (1997) 389:753-8. doi:10.1038/39645

55. Pearce BC, Parker RA, Deason ME, Dischino DD, Gillespie E, Qureshi AA, et al. Inhibitors of cholesterol biosynthesis. 2. Hypocholesterolemic and antioxidant activities of benzopyran and tetrahydronaphthalene analogues of the tocotrienols. J Med Chem (1994) 37:526-41. doi:10.1021/jm00030a012

56. Guthrie N, Gapor A, Chambers AF, Carroll KK. Inhibition of proliferation of estrogen receptor-negative MDA-MB-435 and -positive MCF-7 human breast cancer cells by palm oil tocotrienols and tamoxifen, alone and in combination. J Nutr (1997) 127:544S-8S.

57. He L, Mo H, Hadisusilo S, Qureshi AA, Elson CE. Isoprenoids suppress the growth of murine B16 melanomas in vitro and in vivo. J Nutr (1997) 127:668-74.

58. Mo H, Elson CE. Studies of the isoprenoid-mediated inhibition of mevalonate synthesis applied to cancer chemotherapy and chemoprevention. Exp Biol Med (Maywood) (2004) 229:567-85.

59. Jordan VC. Antiestrogens and selective estrogen receptor modulators as multifunctional medicines. 1. Receptor interactions. J Med Chem (2003) 46:883-908. doi:10.1021/jm020450x

60. Jordan VC. Antiestrogens and selective estrogen receptor modulators as multifunctional medicines. 2. Clinical considerations and new agents. J Med Chem (2003) 46:1081-111. doi:10.1021/jm020450x

61. Cunha GR, Forsberg JG, Golden R, Haney A, Iguchi T, Newbold R, et al. New approaches for estimating risk from exposure to diethylstilbestrol. Environ Health Perspect (1999) 107(Suppl 4):625-30. doi:10.2307/3434555

Conflict of Interest Statement: The authors declare that the research was conducted in the absence of any commercial or financial relationships that could be construed as a potential conflict of interest.

Copyright (๑ 2016 Khallouki, de Medina, Caze-Subra, Bystricky, Balaguer, Poirot and Silvente-Poirot. This is an open-access article distributed under the terms of the Creative Commons Attribution License (CC BY). The use, distribution or reproduction in other forums is permitted, provided the original author(s) or licensor are credited and that the original publication in this journal is cited, in accordance with accepted academic practice. No use, distribution or reproduction is permitted which does not comply with these terms. 